\title{
Potential of Novel EPO Derivatives in Limb Ischemia
}

\author{
Dhiraj Joshi, ${ }^{1}$ Janice Tsui, ${ }^{1}$ Rebekah Yu, ${ }^{1}$ Xu Shiwen,, ${ }^{2}$ Sadasivam Selvakumar, ${ }^{1}$ \\ David J. Abraham, ${ }^{2}$ and Daryll M. Baker ${ }^{1}$
}

${ }^{1}$ Vascular Unit, Division of Surgery and Interventional Science, Royal Free Hospital, University College London (Royal Free Campus), Pond Street, London NW3 2QG, UK

${ }^{2}$ Centre for Rheumatology, University College London (Royal Free Campus), Pond Street, London NW3 2QG, UK

Correspondence should be addressed to Janice Tsui, janice.tsui@ucl.ac.uk

Received 15 July 2011; Accepted 12 December 2011

Academic Editor: Sidney G. Shaw

Copyright () 2012 Dhiraj Joshi et al. This is an open access article distributed under the Creative Commons Attribution License, which permits unrestricted use, distribution, and reproduction in any medium, provided the original work is properly cited.

Erythropoietin (EPO) has tissue-protective properties, but it increases the risk of thromboembolism by raising the haemoglobin concentration. New generation of EPO derivatives is tissue protective without the haematopoietic side effects. Preclinical studies have demonstrated their effectiveness and safety. This paper summarizes the development in EPO derivatives with emphasis on their potential use in critical limb ischaemia.

\section{Introduction}

Critical limb ischaemia (CLI) causes considerable morbidity and mortality. Surgical and endovascular revascularization are the main treatment options. One-fourth of patients presenting with CLI undergo a major amputation, primarily because they are not suitable for revascularization [1]. Pharmacotherapy has negligible role in the management of CLI. Prostacyclin is the only disease-modifying drug with proven efficacy in reducing rest pain and/or ulcer size in CLI via its vasodilatory effects on the distal circulation [2]. The TransAtlantic Inter Society Consensus document on peripheral vascular disease (TASC) has recommended the use of iloprost in CLI to avoid or delay major amputation [3]. There is limited evidence supporting the use of other vasoactive drugs such as pentoxifylline, cilostozol, and L-Arginine (precursor of nitric oxide) in the treatment of CLI [4].

More recently, the possibility of using recombinant formulations of growth factors to augment the development of collaterals and new capillaries from pre-existing blood vessels has been explored. This is otherwise known as therapeutic angiogenesis [5]. Prominent among these techniques is the intra-arterial or intramuscular administration of vascular endothelial growth factor (VEGF) plasmid DNA $\left(\mathrm{phVEGF}_{165}\right)$ [6] where initial studies in patients with CLI demonstrated an increase in angiogenesis [7]. Other than gene therapy, clinical studies have been carried out to inject bone-marrow mononuclear cells intramuscularly in CLI. The innate ability of bone marrow cells to supply endothelial progenitor cells and release endothelial growth factors and cytokines also helped induce angiogenesis [8]. However, despite a demonstration of increased angiogenesis, improvement in clinical endpoints was less clear. This is likely to be due to the complex pathology involved within the ischaemic tissue [9].

Tissue protection may be an alternative therapeutic strategy for CLI where reducing tissue damage and maintaining tissue viability may improve outcome of current treatments and contribute to limb salvage. It has been shown previously that limb ischaemia causes apoptosis of skeletal muscle [19]. Therefore, the use of tissue protective agents to decrease apoptosis and inflammation, either alone or in combination with other therapeutic strategies, may be beneficial.

Erythropoietin (EPO) has tissue protective properties that have been described extensively [20,21]. We have recently shown that there is expression and upregulation of EPO receptors (EPORs) in human skeletal muscle [18]. However, EPO triggers profound haematopoiesis that increases the risk of thromboembolism [22]. This may prevent its use in CLI. Lately, nonhematopoietic EPO derivatives have been developed, which avoid its hematopoietic side effects [23]. The aim of this paper is to summarize the developments that 
have taken place so far in the use of EPO derivatives in protection of ischaemic tissue and discuss its potential use in CLI.

\section{EPO and Its Receptors}

Erythropoietin (EPO) belongs to the class-I cytokine family. It is a glycoprotein hormone with a molecular mass of $30.4 \mathrm{kDa}$ [24]. The protein core contains 165 amino acids and the peripheral carbohydrate chains are made up of $4 \mathrm{~N}$ linked oligosaccharides (Figure 1) [25].

Human EPO receptor (EPOR) is a cell surface protein containing 508 amino acids and has a molecular weight of 55 $\mathrm{KDa}$ [26]. It belongs to the cytokine receptor superfamily and contains extracellular, transmembraneous, and intracellular domains [27]. The common $\beta$-chain of IL-3/IL-5/GM-CSF receptor (also called CD131 or $\beta$-common receptor) belongs to the same super-family. The molecular weight of $\beta$-common receptor $(\beta c \mathrm{R})$ is approximately $130 \mathrm{kDa}[23]$. The $\mathrm{EPO}$ molecule binds to two EPOR subunits (EPOR dimers or $\left.(\mathrm{EPOR})_{2}\right)$ to bring about the haemopoietic action. In contrast, the EPO molecule binding to two $\beta \mathrm{cR}$ subunits sandwiching two EPOR subunits mediates the tissue protective function [23]. The four subunits constitute the heteroreceptor complex, which binds to the EPO molecule and activates cell signalling (Figure 2). The intracellular or cytoplasmic domain of all cytokine receptors is intangibly related to a Janus family tyrosine protein kinase 2 (JAK2). The binding of EPO to its receptor (EPOR homodimer or $\beta \mathrm{CR}$ and EPOR) induces a conformational change in the receptor, activating a downstream signalling pathway that leads to the transcription of new proteins that determine the fate of the cell [28].

Endogenous EPO is essential for the maturation and survival of erythrocytes and thus maintaining the normal haemoglobin concentration. In chronic renal failure, the kidneys cease to make EPO, and commercially available preparations of recombinant human EPO (rHuEPO) are mainly used to treat anaemia secondary to chronic renal failure [30]. In addition to its role in prolonging the survival of erythrocytes, EPO has been shown to exert anti-apoptotic and antiinflammatory effects in neural and cardiac tissue both in vitro and in vivo. Clinical trials have also confirmed its beneficial effects in stroke and myocardial infarction $[21,31]$.

However, the ability of rHuEPO to bond with EPOR in extrahaematopoietic tissues including vascular endothelium is about 50 times less than that in the erythroid cells [32]. Hence, the dose of EPO required to attain a tissue protective effect in heart and brain ischaemia is much higher than that used for the management of anaemia in renal failure. In CLI, the volume of ischaemic tissue is even greater than that in heart and brain ischaemia, therefore higher doses still may be required to achieve a therapeutic effect. This will cause an unfavorable increase in the haematocrit and blood viscosity, which in turn will raise the risk of thromboembolism and occlusion of arteries with pre-existing disease [33, 34]. Another concern is a potential effect on tumour progression due to its angiogenic properties [35]. However, recent evidence suggests that this may not be a significant risk [36]. EPO also

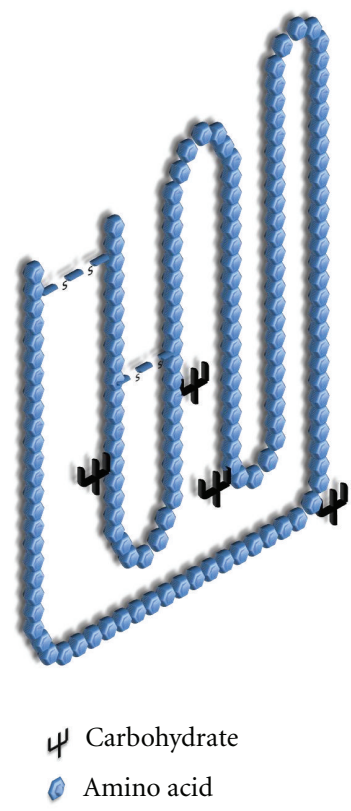

FIgURE 1: A schematic representation of the molecule of EPO. Adapted from Elliott et al. [25]

causes hypertension by its action on vascular smooth muscle cells [37-39].

Due to the potential side effects, most research on the tissue protective effects of EPO in CLI and other tissues has been limited to preclinical models. However, the latest nonhaemopoietic EPO derivatives may overcome the unnecessary side effects and permit the translation of preclinical results into clinical trials [11].

\section{Nonhaematopoietic Derivatives of EPO}

3.1. Carbamylated Erythropoietin (CEPO). CEPO is formed by the chemical modification of the amino acid lysine to homocitrulline. It changes the receptor-binding capability of the EPO molecule [11].

3.2. Asialo EPO. Asialo EPO is formed by decreasing the sialic acid content of rHuEPO by a technique known as the total enzymatic desialylation. Remarkably, the molecule retains its tissue protective property but loses the haemopoietic ability. This also results in the reduction of the half-life of the Asialo EPO to minutes [10].

3.3. Helix-B Surface Peptide (HBSP) [40]. The EPO molecule, a glycoprotein that contains 165 amino acids is folded in such a way that the hydrophobic areas-helixes A, C, and D face away from the surface and are embedded in the extracellular domains of $(\mathrm{EPOR})_{2}$. However, helix B that is hydrophilic points away from the receptor and has wide-ranging tissue-protective properties. Isolating the helix B which is devoid of the primary sequence resulted in a low molecular weight peptide. The spontaneous cyclization of Helix B 


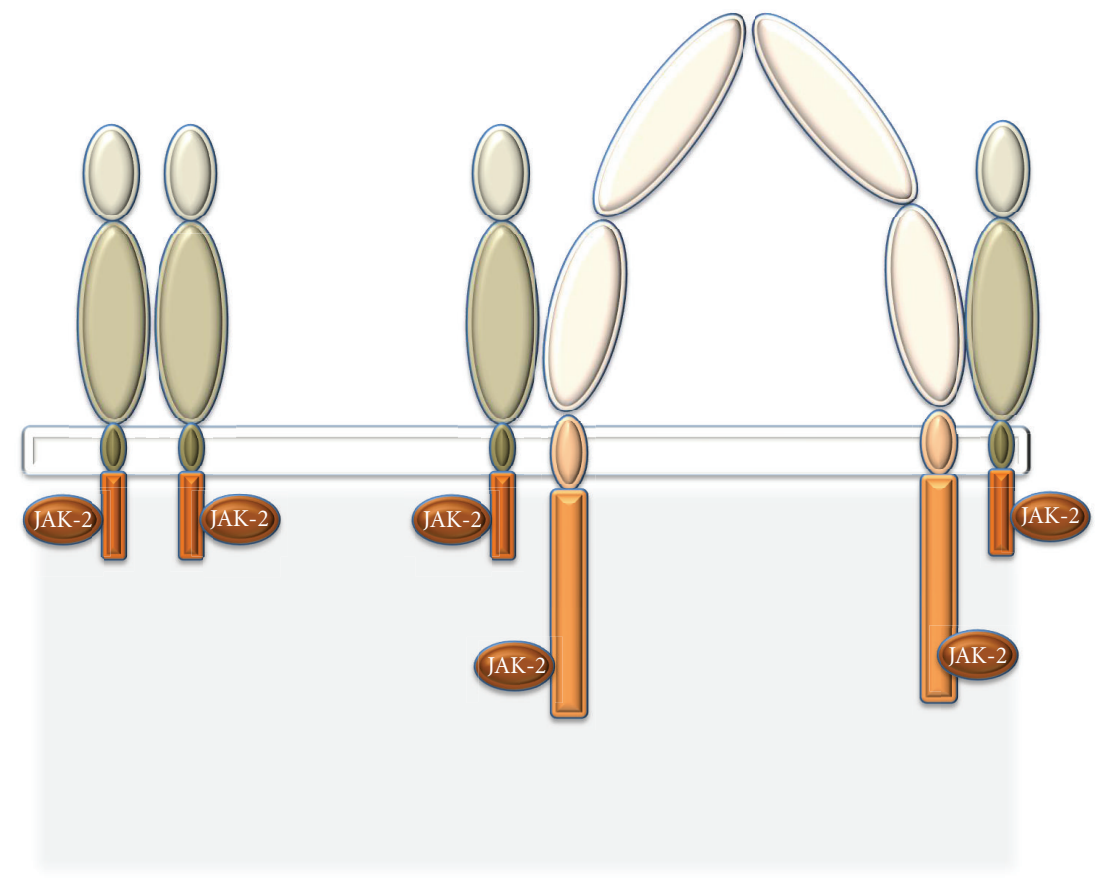

FIGURE 2: Schematic representation of the structure of erythropoietin receptor (EPOR) and beta-common receptor (CD131) on the left and the right hand side, respectively. *Based on Brines et al. [29]. JAK-2 stands for Janus family Tyrosine Protein Kinase 2.

TABLE 1: Recent studies investigating the role of nonhaematopoietic derivatives of EPO.

\begin{tabular}{|c|c|c|c|}
\hline Author & $\begin{array}{l}\text { Nonhaematopoietic } \\
\text { EPO derivative }\end{array}$ & Model & Inference \\
\hline Erbayraktar et al. 2003 [10] & Asialo EPO & $\begin{array}{l}\text { In vivo model of cerebral and spinal } \\
\text { cord ischaemia plus sciatic nerve injury }\end{array}$ & Neuroprotection-recovery of paraplegia \\
\hline Leis et al. 2004 [11] & $\begin{array}{l}\text { Carbamylated } \\
\text { EPO (CEPO) }\end{array}$ & $\begin{array}{l}\text { In vitro and in vivo models of neural } \\
\text { injury }\end{array}$ & $\begin{array}{l}\text { Demonstration of tissue protective } \\
\text { properties of CEPO in neural tissue }\end{array}$ \\
\hline Fiordaliso et al. 2005 [12] & CEPO & $\begin{array}{l}\text { In vivo model of rat myocardial } \\
\text { infarction }\end{array}$ & $\begin{array}{l}\text { Reduction in the size of } \\
\text { myocardial infarct }\end{array}$ \\
\hline Fantacci et al. 2006 [13] & CEPO & $\begin{array}{l}\text { In vivo model of metabolic stress in } \\
\text { mice induced by chronic hypoxia }(\mathrm{CH})\end{array}$ & $\begin{array}{l}\text { CEPO reduced metabolic stress caused } \\
\text { by } \mathrm{CH} \text { and improved cellular survival } \\
\text { independent of haematopoiesis. }\end{array}$ \\
\hline Erbayraktar et al. 2006 [14] & CEPO & $\begin{array}{l}\text { In vivo model of radiosurgically induced } \\
\text { brain injury in rats }\end{array}$ & Decreased necrosis of the brain tissue \\
\hline Erbayraktar et al. 2009 [15] & CEPO and ARA 290 & $\begin{array}{l}\text { In vivo models of decubitus ulcers } \\
\text { and peritonitis }\end{array}$ & $\begin{array}{l}\text { Improved healing and less intraperitoneal } \\
\text { adhesion formation }\end{array}$ \\
\hline Ahmet et al. $2010[16]$ & ARA 290 & In vivo model of myocardial ischemia & $\begin{array}{l}\text { Reduction in the size of infarct and } \\
\text { improvement of ejection fraction }\end{array}$ \\
\hline Joshi et al. 2010 [17] & ARA 290 & In vitro & $\begin{array}{l}\text { Decreased apoptosis of myotubes but } \\
\text { no effect on angiogenesis }\end{array}$ \\
\hline Joshi et al. 2011 [18] & ARA 290 & In vitro & $\begin{array}{l}\text { Decreased ischaemia-induced } \\
\text { inflammation and apoptosis of myotubes }\end{array}$ \\
\hline
\end{tabular}

surface peptide (HBSP) gives rise to pyroglutamate HBSP (pHBSP), which is also known as ARA 290. The effective dose of ARA 290 peptide that showed evidence of tissue protection was comparable on a molar basis to those studied for EPO and was higher than that required for EPO-mediated erythropoiesis. For example, in the renal ischaemia model of mice, $0.08 \mathrm{nmol} / \mathrm{kg}$ of bw (equivalent to $300 \mathrm{units} / \mathrm{kg}$ of body weight of EPO) was ineffective, whereas a 10-fold higher dose elicited strong tissue protection [40]. The studies of nonerythropoietic EPO derivatives have been summarised in Table 1.

\section{Mechanism of Action}

Receptor-initiated cell signaling by EPO and its derivatives occurs via multiple molecular cascades, which differ in 
importance depending on the specific tissue or cell type, as well as the type of injury [41]. As in erythropoiesis, the majority of tissue-protective responses begin by the phosphorylation of JAK-2 or JAK-1 [42, 43]. Following JAK-2 phosphorylation, 3 main pathways are activated that result in attenuation of apoptosis: STAT-5/Bcl-xL (Signal Transducers and Activator of Transcription; type 5) [44]; PI3K/Akt (phosphatidyl inositol-3 kinase/Protein Kinase B) [45]; in some tissues including the heart, the MAPK (mitogen-activated protein kinase) pathway is involved [46]. MAPK and P13K/ Akt inhibit caspase activation, thus directly attenuating apoptosis. We have shown that ARA 290 decreases cleaved caspase- 3 in the myotubes subjected to ischaemia [18]. This may indicate that EPO and its derivatives may attenuate apoptosis through the MAPK or P13K/Akt pathway. However, further study is needed to understand completely the interactions of these signaling pathways that ultimately transduce tissue protection in vivo.

\section{Discussion}

It is now known that EPO receptors are present in human skeletal muscle and their expression is elevated in CLI. It has also been shown that a nonhaematopoietic derivative of EPO (ARA 290) decreases inflammation and apoptosis of ischaemic myotubes and may thus be used to selectively enhance the tissue-protective activity of EPO whilst avoiding the haematopoietic side effects in CLI.

The timing of administering EPO derivatives depends on their half-life. CEPO has a half-life of 4-6 hours while AsialoEPO and ARA 290 have a half-life of about 2 minutes. Most in vivo studies have treated animals immediately following ischaemic injury $[15,23]$. In the context of CLI, EPO derivatives may be used at the onset of CLI, either alone or as an adjunct to surgical or endovascular revascularization via systemic administration through intra-arterial, intravenous, or intramuscular routes. Due to the relatively short half-life of currently available compounds, repeated injections may be required. Clinical studies are needed to assess the efficacy of EPO derivatives in patients with CLI and to identify optimal delivery routes and dosing schedules.

\section{Conclusion}

EPO receptors are present in human skeletal muscle and their expression is elevated in CLI. Nonhaematopoietic derivatives of EPO decrease inflammation and apoptosis of ischaemic myotubes whilst avoiding haematopoietic side effects. They may thus reduce tissue damage and provide a unique ther-apeutic alternative for CLI.

\section{References}

[1] A. J. Henry, N. D. Hevelone, M. Belkin, and L. L. Nguyen, "Socioeconomic and hospital-related predictors of amputation for critical limb ischemia," Journal of Vascular Surgery, vol. 53, no. 2, pp. 330-339, 2011.
[2] S. Marchesi, L. Pasqualini, R. Lombardini et al., "Prostaglandin E1 improves endothelial function in critical limb ischemia," Journal of Cardiovascular Pharmacology, vol. 41, no. 2, pp. 249-253, 2003.

[3] J. A. Dormandy and R. B. Rutherford, "Management of peripheral arterial disease (PAD). TASC Working Group. TransAtlantic Inter-Society Consensus (TASC)," Journal of Vascular Surgery, vol. 31, no. 1, part 2, pp. S1-S296, 2000.

[4] Management of Peripheral Arterial Disease (PAD), "TransAtlantic Inter-Society Consensus (TASC)," European Journal of Vascular and Endovascular Surgery, vol. 19, supplemt A, pp. S1-S250, 2000.

[5] S. Takeshita, D. Gal, G. Leclerc et al., "Increased gene expression after liposome-mediated arterial gene transfer associated with intimal smooth muscle cell proliferation. In vitro and in vivo findings in a rabbit model of vascular injury," Journal of Clinical Investigation, vol. 93, no. 2, pp. 652-661, 1994.

[6] J. M. Isner, A. Pieczek, R. Schainfeld et al., "Clinical evidence of angiogenesis after arterial gene transfer of phVEGF165 in patient with ischaemic limb," The Lancet, vol. 348, no. 9024, pp. 370-374, 1996.

[7] I. Baumgartner, A. Pieczek, O. Manor et al., "Constitutive expression of phVEGF165 after intramuscular gene transfer promotes collateral vessel development in patients with critical limb ischemia," Circulation, vol. 97, no. 12, pp. 1114-1123, 1998.

[8] E. Tateishi-Yuyama, H. Matsubara, T. Murohara et al., "Therapeutic angiogenesis for patients with limb ischaemia by autologous transplantation of bone-marrow cells: a pilot study and a randomised controlled trial," The Lancet, vol. 360, no. 9331, pp. 427-435, 2002.

[9] K. A. Webster, "Therapeutic angiogenesis: a complex problem requiring a sophisticated approach," Cardiovascular Toxicology, vol. 3, no. 3, pp. 283-297, 2003.

[10] S. Erbayraktar, G. Grasso, A. Sfacteria et al., "Asialoerythropoietin is a nonerythropoietic cytokine with broad neuroprotective activity in vivo," Proceedings of the National Academy of Sciences of the United States of America, vol. 100, no. 11, pp. 6741-6746, 2003.

[11] M. Leis, P. Gliezzi, G. Grasso et al., "Derivatives of erythropoitein that are tissue protective but not erythropoietic," Science, vol. 305, no. 5681, pp. 239-242, 2004.

[12] F. Fiordaliso, S. Chimenti, L. Staszewsky et al., "A nonerythropoietic derivative of erythropoietin protects the myocardium from ischemia-reperfusion injury," Proceedings of the National Academy of Sciences of the United States of America, vol. 102, no. 6, pp. 2046-2051, 2005.

[13] M. Fantacci, P. Bianciardi, A. Caretti et al., "Carbamylated erythropoitein ameliorates the metabolic stress induced in vivo by severe chronic hypoxia," Proceedings of the National Academy of Sciences of the United States of America, vol. 103, no. 46, pp. 17531-17536, 2006.

[14] S. Erbayraktar, N. de Lanerolle, A. de Lotbinière et al., "Carbamylated erythropoietin reduces radiosurgically-induced brain injury," Molecular Medicine, vol. 12, no. 4-6, pp. 74-80, 2006.

[15] Z. Erbayraktar, S. Erbayraktar, O. Yilmaz, A. Cerami, T. Coleman, and M. Brines, "Nonerythropoietic tissue protective compounds are highly effective facilitators of wound healing," Molecular Medicine, vol. 15, no. 7-8, pp. 235-241, 2009.

[16] I. Ahmet, H. J. Tae, M. Juhaszova et al., "A small nonerythropoietic helix B surface peptide based upon erythropoietin structure is cardioprotective against ischemic myocardial damage," Molecular Medicine, vol. 17, no. 3-4, pp. 194-200, 2011. 
[17] D. Joshi, J. Tsui, X. Shiwen et al., "Helix-B peptide of erythropoietin could be used as pharmacotherapy in critical limb ischaemia," British Journal of Surgery, vol. 98, no. 2, 2011.

[18] D. Joshi, J. Tsui, H. Patel et al., "Role of erythropoietin receptors and ligands in attenuating inflammation and apoptosis in critical limb ischemia," Journal of Vascular Surgery, vol. 53, no. 6, supplement, p. 80S, 2011.

[19] R. G. Mitchell, B. D. Duscha, J. L. Robbins et al., "Increased levels of apoptosis in gastrocnemius skeletal muscle in patients with peripheral arterial disease," Vascular Medicine, vol. 12, no. 4, pp. 285-290, 2007.

[20] H. Ehrenreich, K. Weissenborn, H. Prange et al., "Recombinant human erythropoietin in the treatment of acute ischemic stroke," Stroke, vol. 40, no. 12, pp. e647-e656, 2009.

[21] N. P. Riksen, D. J. Hausenloy, and D. M. Yellon, "Erythropoietin: ready for prime-time cardioprotection," Trends in Pharmacological Sciences, vol. 29, no. 5, pp. 258-267, 2008.

[22] C. L. Bennett, S. M. Silver, B. Djulbegovic et al., "Venous thromboembolism and mortality associated with recombinant erythropoietin and darbepoetin administration for the treatment of cancer-associated anemia," JAMA, vol. 299, no. 8, pp. 914-924, 2008.

[23] M. Brines, G. Grasso, F. Fiordaliso et al., "Erythropoietin mediates tissue protection through an erythropoietin and common $\beta$-subunit heteroreceptor," Proceedings of the National Academy of Sciences of the United States of America, vol. 101, no. 41, pp. 14907-14912, 2004.

[24] J. M. Davis, T. Arakawa, T. W. Strickland, and D. A. Yphantis, "Characterization of recombinant human erythropoietin produced in Chinese hamster ovary cells," Biochemistry, vol. 26, no. 9, pp. 2633-2638, 1987.

[25] S. Elliott, T. Lorenzini, D. Chang, J. Barzilay, and E. Delorme, "Mapping of the active site of recombinant human erythropoietin," Blood, vol. 89, no. 2, pp. 493-502, 1997.

[26] M. Budarf, K. Huebner, B. Emanuel et al., "Assignment of the erythropoietin receptor (EPOR) gene to mouse chromosome 9 and human chromosome 19," Genomics, vol. 8, no. 3, pp. 575-578, 1990.

[27] J. F. Bazan, "A novel family of growth factor receptors: a common binding domain in the growth hormone, prolactin, erythropoietin and IL-6 receptors, and the p75 IL-2 receptor $\beta$-chain," Biochemical and Biophysical Research Communications, vol. 164, no. 2, pp. 788-795, 1989.

[28] D. M. Wojchowski and T. C. He, "Signal transduction in the erythropoietin receptor system," Stem Cells, vol. 11, no. 5, pp. 381-392, 1993.

[29] M. Brines and A. Cerami, "Emerging biological roles for erythropoietin in the nervous system," Nature Reviews Neuroscience, vol. 6, no. 6, pp. 484-494, 2005.

[30] C. G. Winearls, "Treatment of the anaemia of chornic renal failure with recombinant human erythropoietin," Drugs, vol. 38, no. 3, pp. 342-345, 1989.

[31] H. Ehrenreich, M. Hasselblatt, C. Dembowski et al., "Erythropoietin therapy for acute stroke is both safe and beneficial," Molecular Medicine, vol. 8, no. 8, pp. 495-505, 2002.

[32] R. Yamaji, T. Okada, M. Moriya et al., "Brain capillary endothelial cells express two forms of erythropoietin receptor mRNA," European Journal of Biochemistry, vol. 239, no. 2, pp. 494-500, 1996.

[33] A. Mingoli, P. Sapienza, A. Puggioni, C. Modini, and A. Cavallaro, "A possible side-effect of human erythropoietin therapy: thrombosis of peripheral arterial reconstruction," European Journal of Vascular and Endovascular Surgery, vol. 18, no. 3, pp. 273-274, 1999.
[34] P. Zaoui, F. Bayle, J. Maurizi, M. Foret, S. DalSoglio, and P. Vialtel, "Early thrombosis in kidney grafted into patient treated with erythropoietin," The Lancet, vol. 2, no. 8617, p. 956, 1988.

[35] M. Dicato and L. Plawny, "Erythropoietin in cancer patients: pros and cons," Current Opinion in Oncology, vol. 22, no. 4, pp. 307-311, 2010.

[36] M. E. Hardee, J. P. Kirkpatrick, S. Shan et al., "Human recombinant erythropoietin (rEpo) has no effect on tumour growth or angiogenesis," British Journal of Cancer, vol. 93, no. 12, pp. 1350-1355, 2005.

[37] H. Schiffl and S. M. Lang, "Hypertension induced by recombinant human erythropoietin (rHU-EPO) can be prevented by indomethacin: pathogenetic role of cytosolic calcium," European Journal of Medical Research, vol. 2, no. 3, pp. 97-100, 1997.

[38] S. Kuriyama, G. Tokudome, H. Tomonari et al., "Effect of human recombinant erythropoietin (Epo) on cellular $\mathrm{Ca}^{2+}, \mathrm{Na}^{+}$, and $\mathrm{K}^{+}$regulation of vascular smooth muscle cells grown in vitro- - a new insight into the pathogenesis of Epo induced hypertension," Japanese Journal of Nephrology, vol. 35, no. 6, pp. 671-678, 1993.

[39] Z. Ni, X. Q. Wang, and N. D. Vaziri, "Nitric oxide metabolism in erythropoietin-induced hypertension: effect of calcium channel blockade," Hypertension, vol. 32, no. 4, pp. 724-729, 1998.

[40] M. Brines, N. S. A. Patel, P. Villa et al., "Nonerythropoietic, tissue-protective peptides derived from the tertiary structure of erythropoietin," Proceedings of the National Academy of Sciences of the United States of America, vol. 105, no. 31, pp. 10925-10930, 2008.

[41] M. Brines and A. Cerami, "Erythropoietin-mediated tissue protection: reducing collateral damage from the primary injury response," Journal of Internal Medicine, vol. 264, no. 5, pp. 405-432, 2008.

[42] P. Rafiee, Y. Shi, J. Su, K. A. Pritchard, J. S. Tweddell, and J. E. Baker, "Erythropoietin protects the infant heart against ischemia-reperfusion injury by triggering multiple signaling pathways," Basic Research in Cardiology, vol. 100, no. 3, pp. 187-197, 2005.

[43] M. Digicaylioglu, G. Garden, S. Timberlake, L. Fletcher, and S. A. Lipton, "Acute neuroprotective synergy of erythropoietin and insulin-like growth factor I," Proceedings of the National Academy of Sciences of the United States of America, vol. 101, no. 26, pp. 9855-9860, 2004.

[44] T. C. Wen, Y. Sadamoto, J. Tanaka et al., "Erythropoietin protects neurons against chemical hypoxia and cerebral ischemic injury by up-regulating Bcl-x," Journal of Neuroscience Research, vol. 67, no. 6, pp. 795-803, 2002.

[45] C. J. Parsa, A. Matsumoto, J. Kim et al., "A novel protective effect of erythropoietin in the infarcted heart," Journal of Clinical Investigation, vol. 112, no. 7, pp. 999-1007, 2003.

[46] J. E. Baker, D. Kozik, A. K. Hsu, X. Fu, J. S. Tweddell, and G. J. Gross, "Darbepoetin alfa protects the rat heart against infarction: dose-response, phase of action, and mechanisms," Journal of Cardiovascular Pharmacology, vol. 49, no. 6, pp. 337345, 2007. 


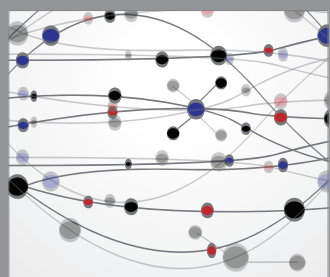

The Scientific World Journal
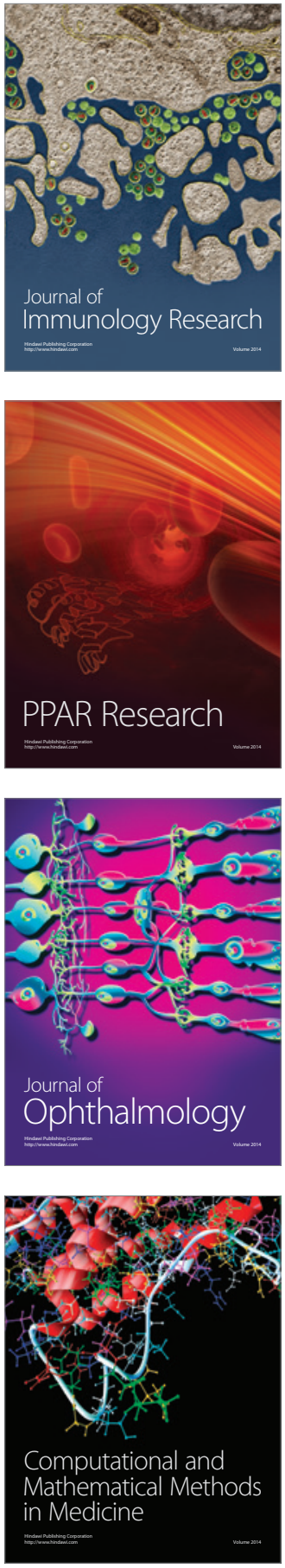

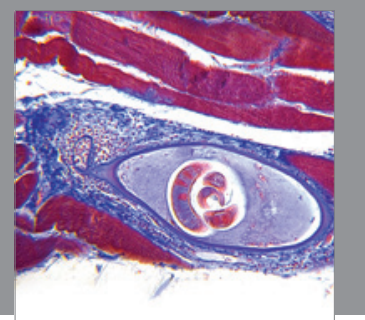

Gastroenterology

Research and Practice
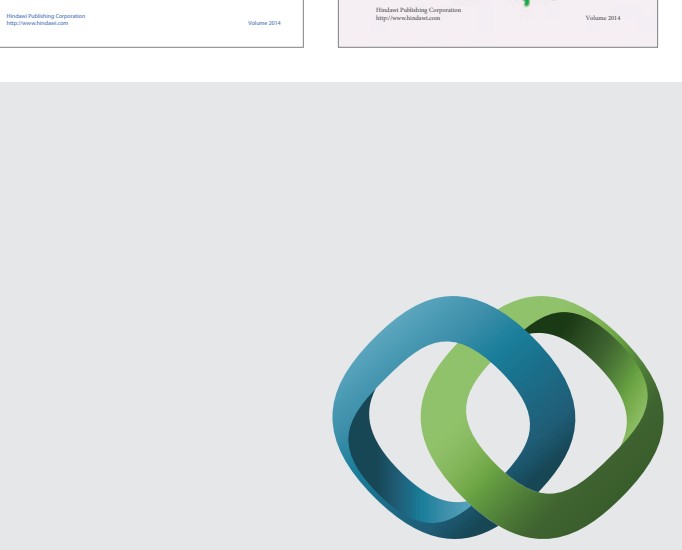

\section{Hindawi}

Submit your manuscripts at

http://www.hindawi.com
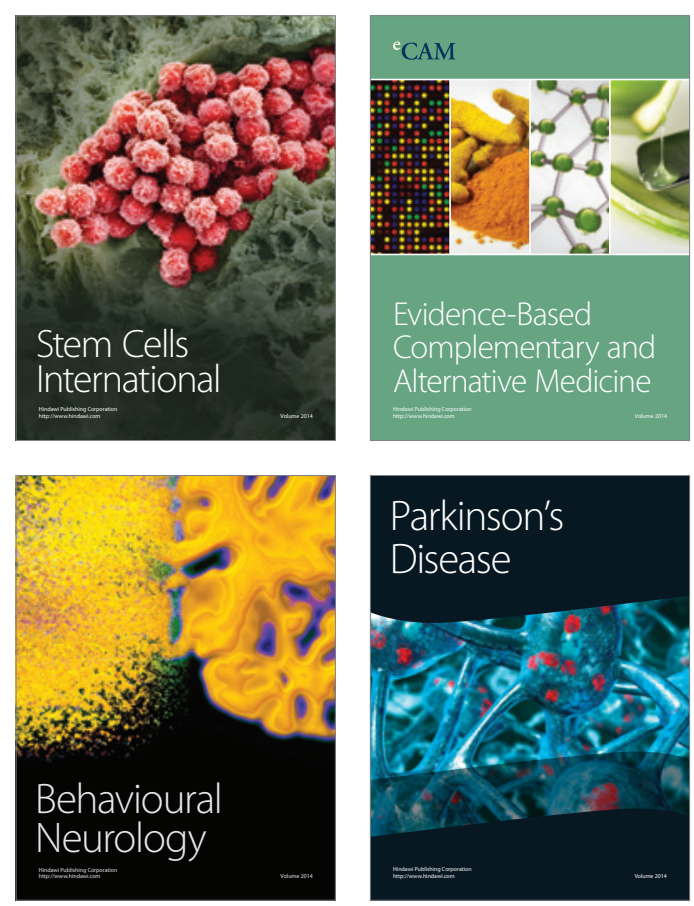

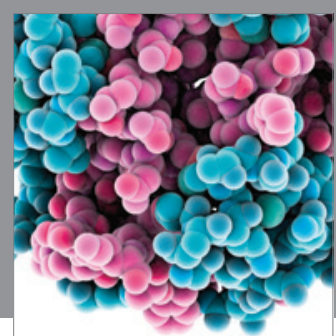

Journal of
Diabetes Research

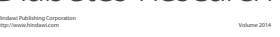

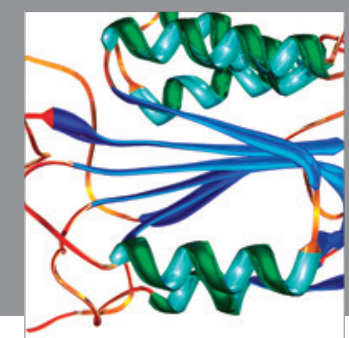

Disease Markers
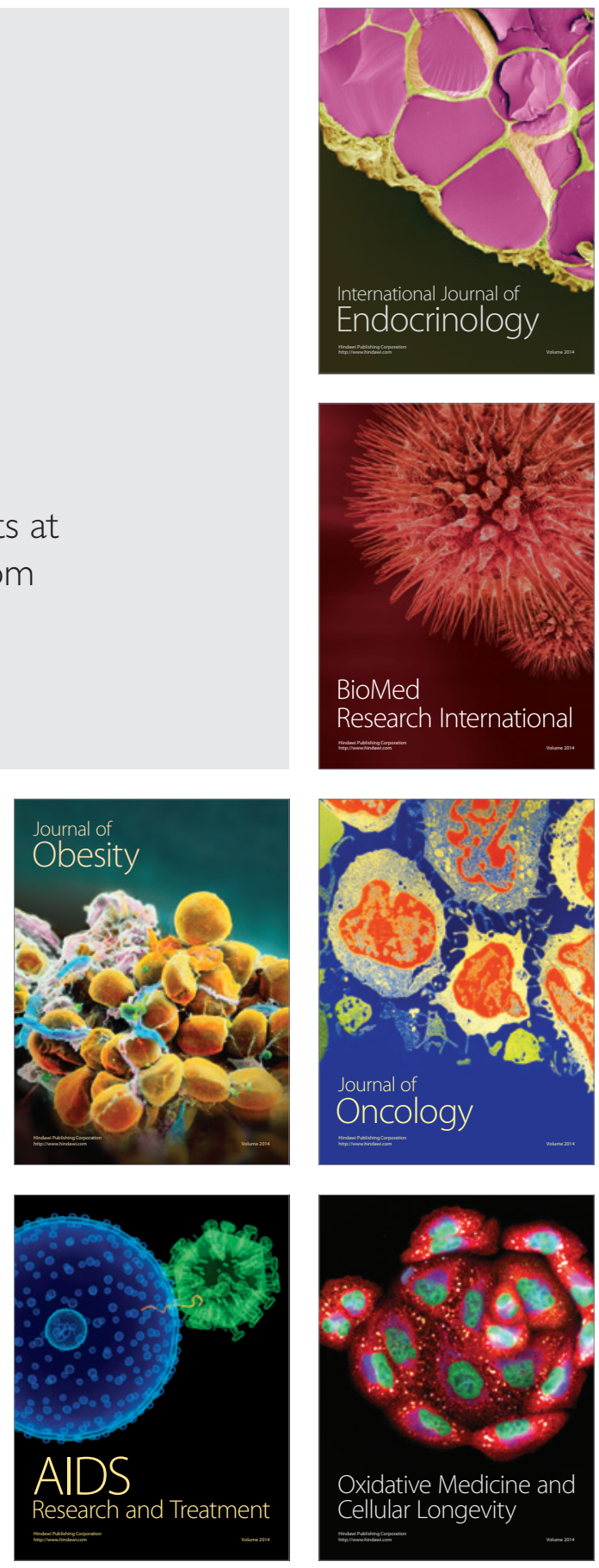